\title{
Extraction of Tannin by Acacia mearnsii with Supercritical Fluids
}

\author{
Marcia Regina Pansera ${ }^{1}$, Gelson Antonio Iob ${ }^{1}$, Ana Cristina Atti-Santos ${ }^{1,2}$, Marcelo \\ Rossato $^{1,3}$, Luciana Atti-Serafini ${ }^{1,2}$ and Eduardo Cassel $^{4}$ \\ ${ }^{1}$ Instituto de Biotecnologia; ${ }^{2}$ Departamento de Física e Química; ${ }^{3}$ Departamento de Ciências Exatas e da \\ Natureza; Universidade de Caxias do Sul; Rua Francisco Getúlio Vargas, 1130; 95001-970; Caxias do Sul - RS - \\ Brazil. ${ }^{4}$ Faculdade de Química e Faculdade de Engenharia; Pontifícia Universidade Católica do Rio Grande do \\ Sul; Av. Ipiranga, 6681; 90619-900; Porto Alegre - RS - Brazil
}

\begin{abstract}
Studies were carried out on solvent and supercritical extraction to obtain natural tannins. The results showed that the best co-solvent to extract tannin with $\mathrm{CO}_{2}$ supercritical was water with a concentration of $5.0 \%$ and the best trap rinse solvent was methanol.
\end{abstract}

Key words: Co-solvents, tannin, $\mathrm{CO}_{2}$ supercritical

\section{INTRODUCTION}

Tannins are polyphenolic compounds present in plants, foods and beverages (Makkar and Becker, 1998) which are soluble in water and polar organic solvents (Haslam, 1996). Tannin of Acacia mearnsii finds application in the natural tannage of leather, as alternative procedure instead of leather chromium tannage. The traditional tannage process, with chromium, is highly polluent. Brazil produces about 40,000 ton/year of the tannins which represents $90 \%$ of the world extracted from Acacia mearnsii (Deixheimer, 1998). The process used to extract tannins is the hydrosolubilization. Because this process operates with temperatures around $100^{\circ} \mathrm{C}$, the extraction process motives a hydro cracking of sugar and others organic compounds with a darkening of the final product. We studied the supercritical extraction process as alternative procedure to obtain the natural raw material to leather tannage (Readel, 2001). In which supercritical carbon dioxide and polar or non-polar co-solvents were used as solvents. The advantages of supercritical extraction process with regard to hydrosolubilization and solvent extraction are low extraction temperature, short extraction time and absence organic solvent concentration in the extract. Another objective was to compare the different extraction technology (Taylor, 1996).

\section{MATERIAL AND METHODS}

\section{Natural Material}

The raw material, black acacia bark, was provided by EXTRATOS BRASIL. A part of bark was milled with cutting mill (TECNAL - Willye TE 650 ) with $2.0 \mathrm{~mm}$ average particle diameter. In the solvent extraction with Soxhlet apparatus, dry natural material was employed. The dryer used

*Author for correspondence 
was a BIOMATIC Equipment. The tannin was dried for 10 days at $36^{\circ} \mathrm{C}$.

\section{Solvent Extraction Process}

Samples (50 g of dark acacia bark) were extracted with $500 \mathrm{~mL}$ of solvent for $24 \mathrm{~h}$. The extracted solution was concentrated on a SAVANT Lyofilizator.

\section{Supercritical Extraction Process}

A Hewlett Packard 7680 extraction module was used to perform all the experiments. This system consisted of a nozzle/trap assembly that acted as a controllable variable restrictor, allowing an instantaneous depressurization of the supercritical fluid as well as the decoupling of flow and pressure. The material to be extracted was loaded into a self-sealing extraction cell of $7.0 \mathrm{~mL}$ thickwalled stainless steel thimble. Supercritical fluid extracts were deposited in an internal trap rinsed off into a vial with $1 \mathrm{~mL}$ of hexane and methanol. Samples ( $0.4 \mathrm{~g}$ of bark) were extracted with supercritical carbon dioxide according to the described procedure, where different experiments to optimize the extraction conditions were done. The operation temperature and pressure ranges tested were 40 to $80^{\circ} \mathrm{C}$ and 150 to 200 bar, respectively. All other variables were kept constant: $\mathrm{CO}_{2}$ flow, $2.0 \mathrm{~mL} / \mathrm{min}$; and extraction time, 30 minutes. The pressure and temperature conditions tested in experiments are shown in Table 1.

Table 1 - Pressure and temperature experimental condition

\begin{tabular}{c|c|c|c}
\hline $\mathbf{T}\left({ }^{\circ} \mathbf{C}\right)$ & $\mathbf{P}(\mathbf{b a r})$ & $\mathbf{T}\left({ }^{\circ} \mathbf{C}\right)$ & $\mathbf{P}(\mathbf{b a r})$ \\
\hline 40 & 200 & 40 & 250 \\
50 & 205 & 60 & 204 \\
60 & 150 & 80 & 155 \\
60 & 182 & 60 & 253 \\
70 & 201 & 80 & 202 \\
80 & 155 & 80 & 253 \\
\hline
\end{tabular}

\begin{abstract}
Analysis
The identification of tannins was made by thin layer chromatography (TLC). The analyses were run with standard compounds, catequin and tannic acid, using aluminum cromatofoils. Plates were developed using ethyl acetate:acetic acid (20:4) as the mobile phase. After drying, tannic acid was viewing using $\mathrm{FeCl}_{3}$ (Sharma et al., 1998).

The quantification of tannins was made by spectrophotometry (BECKMANN Model Life Science). Standard solutions were formulated by Folin Denis reagent and the calibration curve was developed at $725 \mathrm{~nm}$ (Seigler et al., 1986).
\end{abstract}

\section{RESULTS AND DISCUSSION}

\section{Solvent Extraction Process}

Three organic solvents were tested to obtain the tannin with Soxhlet Apparatus: ethanol, dimethyl ether, and n-hexane. The experimental results, using TLC showed that n-hexane and dimethyl ether solubilizated only non-polar organic compounds presented in acacia bark, while the ethanol extracted the tannin compounds. The results for ethanol extract can be seen in Fig. 1.

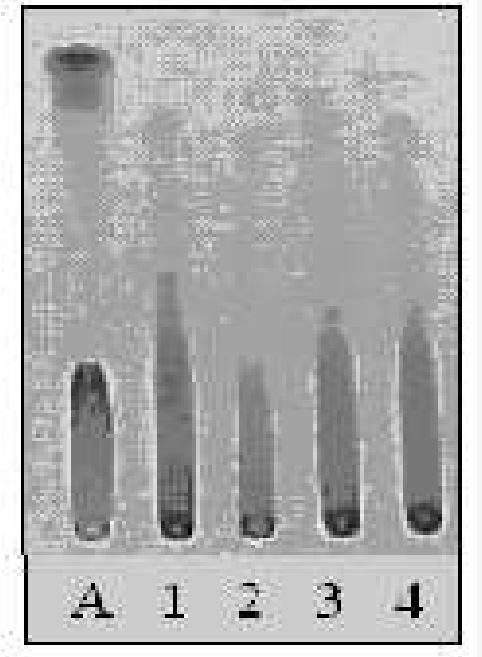

Figure 1 - TLC ethanol extract from acacia bark (1-dry and milled; 2-dry and entire; 3-natural and milled; 4-natural and entire; A-tannic acid standard)

With regard to quantification of tannins by ethanol, using spectrophotometry analysis, the results are written in Table 2 . Sample 1 presented 
higher tannins concentration, but a milled and dry bark was not feasible in the industrial process.

\section{Supercritical Extraction Process}

The supercritical carbon dioxide extraction did not present good results. As alternative on selectivity and quantity augment of extracts obtained was cosolvents addition (Taylor, 1996). Four solvents as co-solvents were tried in the process: acetone, methanol, ethanol and water. The co-solvents concentration employed in the experiments to select the best tannins extraction was $5.0 \%$ with regard to carbon dioxide quantity. Fig. 2 showed the concentration of the tannins, percent tannins in acacia bark (p/p), obtained with co-solvents extractions.

Table 2 - Concentration of the tannins extracted by Soxhlet Apparatus (1 - dry and milled; 2-dry and entire; 3 natural and milled; 4 - natural and entire)

\begin{tabular}{c|c|c}
\hline Acacia bark sample & \% tannins in solvent extract $(\mathbf{p} / \mathbf{p})$ & \% tannins in acacia bark (p/p) \\
\hline 1 & 60 & 23,7 \\
2 & 68 & 21,6 \\
3 & 37 & 4,8 \\
4 & 54 & 6,4 \\
\hline
\end{tabular}

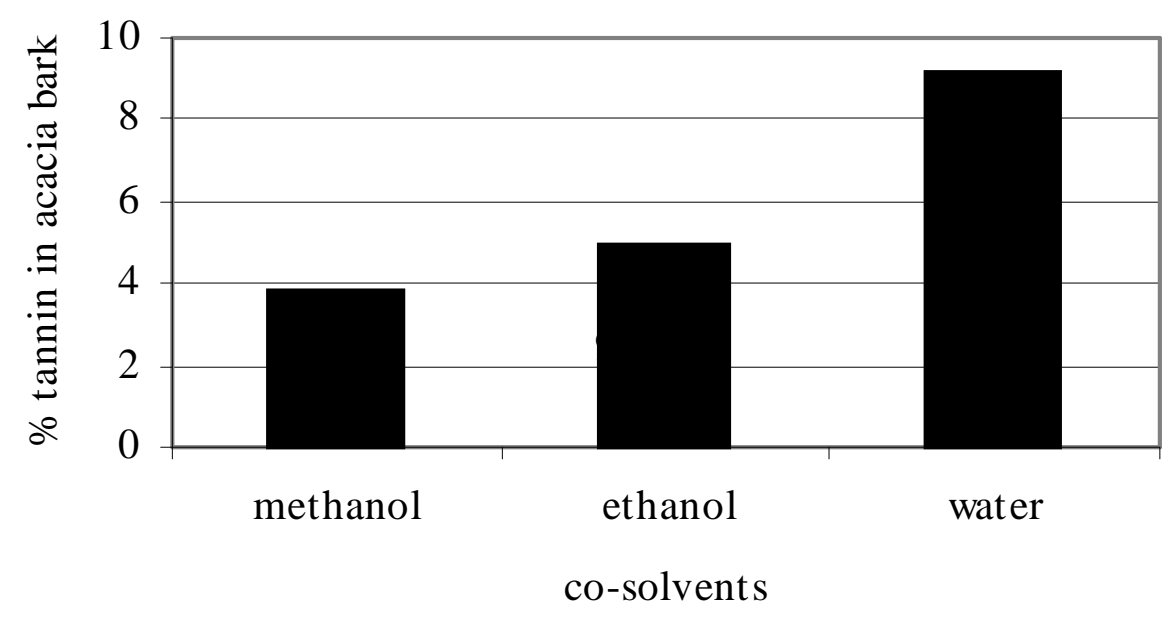

Figure 2 - \% tannins in acacia bark (p/p) extracted with co-solvents $\left(60^{\circ} \mathrm{C}, 200\right.$ bar and $2.0 \mathrm{~mL} \mathrm{CO}_{2} / \mathrm{min}$ )

Table 3 - Yield of tannins extracted by supercritical process (\% p/p) using water and ethanol as co-solvent and $\mathrm{CO}_{2}$ as solvent

\begin{tabular}{c|c|c|c|c|c}
\hline Trap Solvent & Co-solvent & Bark Mass $(\mathbf{g})$ & $\mathbf{T}\left({ }^{\circ} \mathbf{C}\right)$ & P $(\mathbf{b a r})$ & Yield (\% p/p) \\
\hline methanol & ethanol & 0,0538 & 60 & 250 & 9,5 \\
methanol & water & 0,0282 & 60 & 250 & 13,5 \\
n-hexane & water & 0,0106 & 60 & 250 & 6,0 \\
methanol & water & 0,0200 & 60 & 200 & 25,0 \\
n-hexane & water & 0,0092 & 60 & 150 & 1,0 \\
methanol & water & 0,0120 & 60 & 150 & 0,5 \\
n-hexane & water & 0,0100 & 40 & 200 & 0,5 \\
methanol & water & 0,0100 & 40 & 200 & 0,5 \\
n-hexane & water & 0,0100 & 50 & 200 & 6,5 \\
methanol & water & 0,0015 & 50 & 200 & 0,5 \\
\hline
\end{tabular}




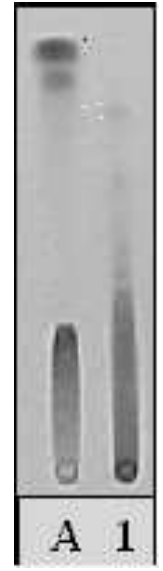

Figure 3 - TLC supercritical extract from acacia bark (1-sample; A-tannic acid standard)

To define the best temperature and pressure condition, after selecting water as the best cosolvent, the extraction experiments were carried with $2.0 \mathrm{~mL} / \mathrm{min}$ during $30 \mathrm{~min}$. Ten experiments were realized changing temperature and pressure conditions, respectively ( 40 to $60^{\circ} \mathrm{C}$; and 150 to 200 bar). The results are presented in Table 3 .

Results showed $\mathrm{T}=60^{\circ} \mathrm{C}$ and $\mathrm{P}=200$ bar as the best conditions to extract tannins. Figure 3 showed the presence of tannic acid in the supercritical extract.

Results indicated the possibility of changing the traditional process (hydrosolubilization) that resulted approximated $20 \%$ of tannins from Acacia mearnsii (Graebin, 2000).

The solvent laboratory experiments with Soxhlet Apparatus were important in this study to demonstrate the poor tannin extraction with nonpolar solvents. The complexity of natural tannins molecules demand experiment test to choose the solvent, therefore it was tried solvents with different polarity.

\section{ACKNOWLEDGMENTS}

Research supported by Universidade of Caxias do Sul, Fundação de Amparo à Pesquisa do Estado do Rio Grande do Sul - FAPERGS, Secretaria de Estado da Ciência e Tecnologia and CNPq.

\section{RESUMO}

Neste trabalho foram utilizados dois processos de extração de tanino vegetal: extração a quente em aparelho Soxhlet e extração com $\mathrm{CO}_{2}$ supercítico. Os resultados mostraram que o melhor co-solvente para extração de taninos com $\mathrm{CO}_{2}$ supercrítico foi a água na concentração de $5 \%$ e o melhor solvente para lavagem do trap foi o metanol.

\section{REFERENCES}

Deixheimer, M. A. (1998), Acácia negra e tanino. Porto Alegre : Tipografia Mercantil S.A.

Graebin, W. (2000), Personal communication. Extratos Brasil Indústria e Comércio Ltda.

Haslam, E. (1996), Natural polyphenols (vegetable tannins) as drugs and medicines: possible modes of action. Journal of Natural Products, 59, 205-215.

Markkar, H. P. S. and Becker, K. (1998), Do tannins in leaves of trees and shrubs from African and Himalayan regions differ in level and activity? Agroforestry Systems, 40, 59-68.

Readel, K.; Seigler, D.; Hwang, K.; Keesy, J. and Seilheimer, S. (2001), Tannins from Mimosid Legumes of Texas and Mexico, Economic Botany, 55 : (2), 212-222.

Sharma, O. P.; Bhat, T. K. and Singh, B. (1998), Thinlayer chromatography of gallic acid, methyl gallate, pyrogallol, phloroglucinol, catechol, resorcinol, hydroquinone, catechin, epicatechin, cinnamic acid, p-coumaric acid, ferulic acid and tannic acid, Journal of Chromatography, 822, 167-171.

Seigler, D. S.; Seilheimer, S.; Keesy, J. and Huang, H. F. (1986), Tannins from four common Acacia species of Texas and Noutheastern Mexico, Economic Botany, 40, 220-232.

Taylor, L. T. (1996), Supercritical Fluid Extraction, Wiley-Interscience Publication, USA. 